\title{
Hypnofertility-Based Nursing Care in Relieving Stress for Women with Need for Fertility Support
}

\author{
Sevcan Fata ${ }^{1 *}$ and Merlinda Alus Tokat ${ }^{2}$ \\ ${ }^{1}$ Research Assistant, Gynecology\&Obstetrics Nursing Department, Dokuz Eylul University Nursing Faculty, Turkey \\ ${ }^{2}$ Associate Professor, Gynecology\&Obstetrics Nursing Department, Dokuz Eylul University Nursing Faculty, Turkey \\ *Corresponding author: Sevcan Fata, Research Assistant, Gynecology\&Obstetrics Nursing Department, Dokuz Eylul \\ University Nursing Faculty, Balcova, Izmir, Turkey
}

\section{ARTICLE INFO}

Received: 䶕 January 25, 2021

Published: 幽 February 03, 2021

Citation: Sevcan Fata, Merlinda Alus Tokat. Hypnofertility-Based Nursing Care in Relieving Stress for Women with Need for Fertility Support. Biomed J Sci \& Tech Res 33(4)-2021. BJSTR. MS.ID.005428.

\section{Keywords: Nursing; Fertility;} Hypnofertility; Hypnofertility-Based

\section{ABSTRACT}

Fertility problem is a major source of stress for couples. Stress is also known to play an important role in reducing fertility. Hypnofertility is a method that can be used to relieve stress. The basis of Hypnofertility was constituted by HypnoBirthing philosophy. "Hypnofertility Support Program" was created by HypnoBirthing Institute educator Sherry Gilbert in 2013 to ensure the use of Hypnofertility on couples living fertility problems. It's the basic principle is that fertility is a natural function. In this article, a samlpe intervention plan based on an Hypnofertility Support Program has been prepared that nurses can perform to women who are taking fertility support from the first encounter until the last meeting. In the intervention plan, ways stress affect fertility and initiatives that can be perform for areas affected were explained in detail. The use of HypnofertilityBased nursing care will provide a holistic, systematic and based on knowledge approach to women. The program can be effective in reducing the stress of women, increasing pregnancy results and changing the confidence and perspective to nurse.

\section{Introduction}

Fertility problem is an important source of stress for couples. Stress is also known to play an important role in reducing fertility [1-6]. In spite of this, worldwide especially in our country only physical interventional procedures are provided to couples during fertility treatment. Nurses working in the fertility clinic support women in subjects such as training on the use of ovulation induction drugs, follow-up during examination, technical procedures such as pre-embryo transfer or post-embryo transfer. The psychological support provided is either insufficient for the woman or it is not effective in reducing stress because it is not professional, systematic and based on a specific method. The use of systematic, holistic and knowledge-based approaches to women by nurses who work with women with fertility problems may be effective in reducing women's stress, increasing pregnancy outcomes, and changing the perspective and confidence in nurses. This approach may also be an important indicator of the professionalism of the nurse.

When we look at the practices applied to women to reduce stress, we see that one of them is Hypnofertility, which has been applied recently. Hypnofertility argues that the brain strongly affects the body and fertility is a natural function. The purpose of this article is to embody the use of Hypnofertility in nursing care, which will provide a systematic approach to reduce the stress of women who receive fertility support. By using Hypnofertility, it is aimed to create a sample intervention plan that health professionals can use to reduce the negative messages that women consciously or unconsciously recorded from the intrauterine life and the stress triggered by them, positively affect consciousness and subconsciousness, and cope with stressful situations.

\section{Mind-Body Map and Neuroendocrine Effect of Stress on Fertility}

The brain records every experience from intrauterine life through to adulthood and consciously or unconsciously stores it in long- or short-term memory. Negative emotional responses are transmitted by the brain biochemically and electrically. These messages are released directly into the bloodstream and transmit to the hypothalamic / pituitary / gonadal (HPG) axis, which has hormonal responsibility in reproduction [7]. Hypothalamus is responsible for the induction of germ cells such as sperm and 
ovum, and the regulation of hormonal balance [8]. Emotionally originated messages are sent to the brain through the receptors, to the autonomic nervous system. They then are transmitted to the anterior lobe of the pituitary [9]. The hypothalamus does not have a direct neuronal connection with the pituitary but is connected to the pituitary via the blood circulation. During emotional stress, it transmits stress hormones to the pituitary with hypothalamic signals, and at the same time reduces Gonadotropin Releasing Hormone (GnRH) secretion [8].

The pituitary gland is dependent on hypothalamic signals. Before the signals reach the anterior pituitary, GnRH is released into the blood while passing through the hypothalamus [9]. Luteinizing Hormone ( $\mathrm{LH}$ ) and Follicle Stimulating Hormone (FSH) are secreted by stimulating the anterior pituitary, and estrogen and progesterone are secreted by stimulating the ovaries. The hypothalamic / pituitary / gonadal axis is negatively affected as a result of the decrease in hormones under stress [8].

Through emotional stress, the autonomic nervous system is activated and then the sympathetic nervous system is activated, suppressing the hypothalamus. Emotional stress messages received through the frontal, parietal, occipital and temporal lobes of the brain are transmitted to the amygdala, where emotional messages are processed and transmitted to the hippocampus, which acts as a channel. Emotional signals from the amygdala in the hippocampus are transmitted to the hypothalamus to initiate chemical reactions appropriate to the signal. The hypothalamus, which acts as the center, sends messages to the right brain, where the subconscious is affected, and the left brain, where consciousness is affected.

If there are similar messages in the past experiences, these messages are also activated in the right and left brain. It transmits chemical responses to the messages to the anterior pituitary in an efferent way [9]. While it is transmitted to the anterior pituitary, GnRH released into the blood decreases, LH and FSH release from the anterior pituitary and estrogen and progesterone release from the ovaries decrease. Corticotropin Releasing Hormone (CRH) is also released while stimulation goes from the hypothalamus to the anterior pituitary [8,10-12]. This causes Adrenocorticotropic Hormone (ACTH) and $\beta$-endorphin release from the anterior pituitary (Buckley, 2015). $\beta$-endorphin increases cortisol release. ACTH also stimulates the adrenal cortex, epinephrine and cortisol. Vasoconstriction occurs and the blood flow to the ovaries decreases [8,10-13] (Figure 1). Hypnofertility aims to reduce the neuroendocrine effect of stress on fertility and increase natural fertility by reducing the stress of the woman.

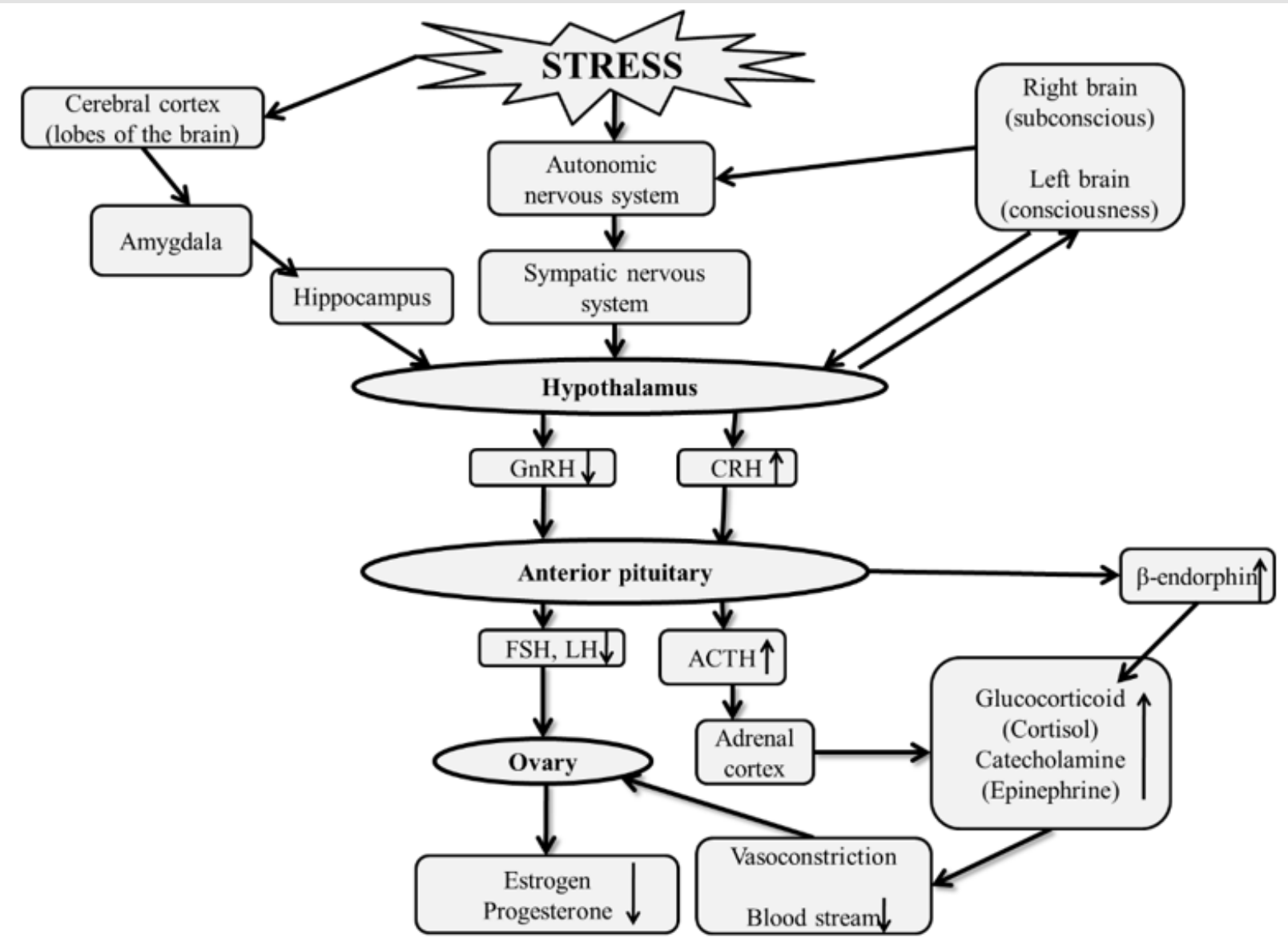

Figure 1: Neuroendocrine Effect of Stress on Fertility. 


\section{Hypnofertility}

The "Hypno Birthing" philosophy forms the basis of Hypnofertility. Hypno Birthing is a birth technique and philosophy developed by Marie F. Mongan, founder of the Hypno Birthing Institute, which physically and psychologically prepares women for birth. Its basic principle is that childbearing is a normal, natural and healthy function for women., it aims to ensure that the woman is free from her fears and relax by prenatal education and applying selfhypnosis at birth [14]. Based on the Hypno Birthing philosophy, the "Hypnofertility Support Program" was created in 2013 by the Hypno Birthing Institute trainer, Sherry Gilbert, to ensure its use in couples with fertility problems. Its basic principle is that fertility is a natural function [7]. The program is based on powerful and effective mindbody interaction. The mind, consciously or unconsciously, records all of our experiences and external messages since our childhood. The mind functionally consists of consciousness, subconscious and critical factors [7].

Consciousness is the part that makes analysis, logic, and where reality takes place. It records short-term memory. It includes personal boundaries, attitudes, beliefs, decisions, hope for the future, and thoughts. Women with fertility problems often hear words such as infertile, unsuccessful, sterile, complete failure, complex, difficult, dysfunction, disorder, damage, deficiency, too late. Experiences and these negative messages from outside turn into social isolation by negatively affecting personal boundaries; attitudes such as blame, jealousy; the belief that treatment and itself will fail; the decision to stop treatment; to despair about pregnancy; thoughts such as difficult, complex [7] (Figure 2).

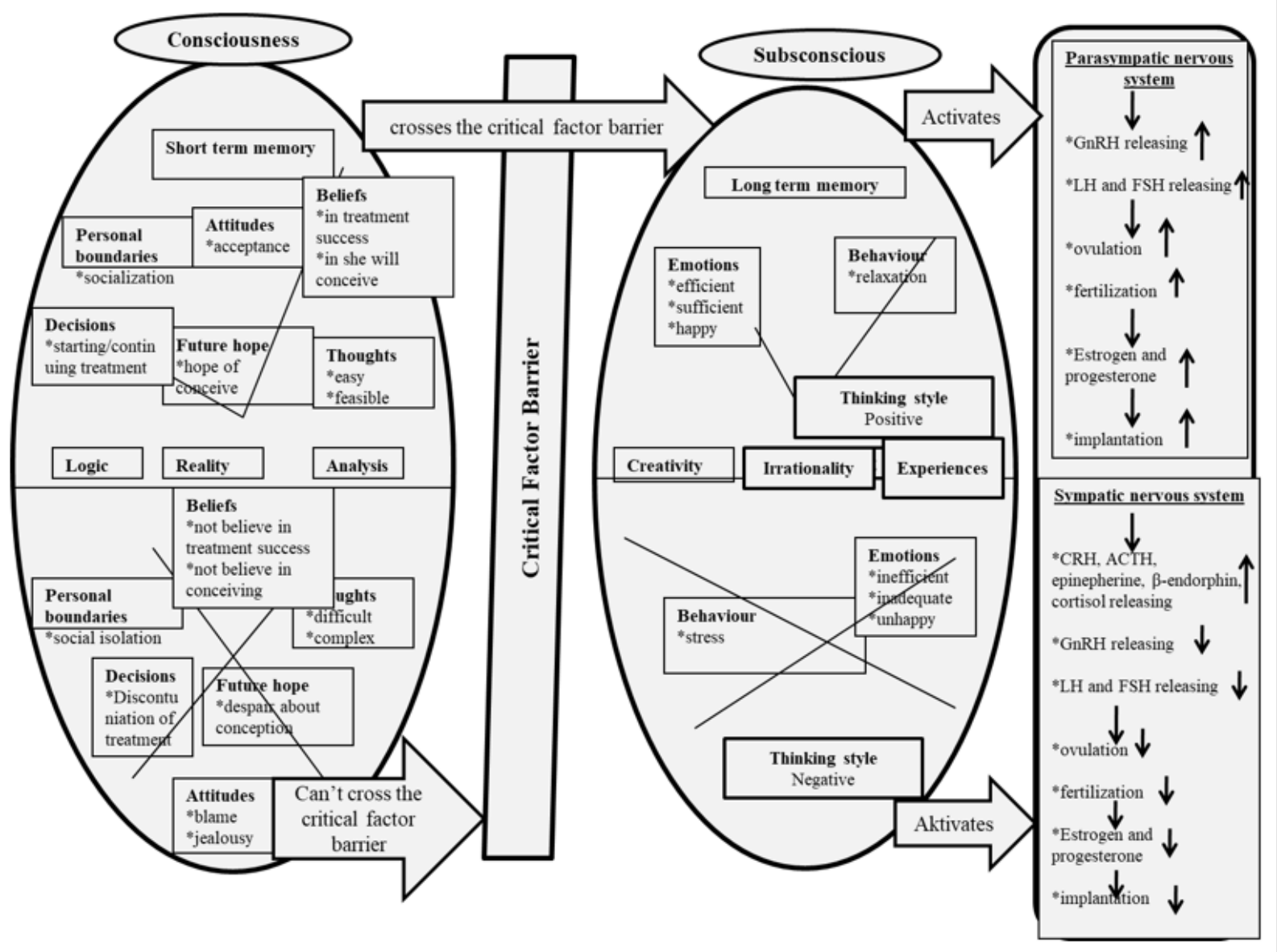

Figure 2: Consciousness, critical factor, subconscious and autonomic nervous system interaction in Hypnofertility.

Subconscious is the creative, emotional part that accepts without separating right or wrong like the computer, does not think rationally. It records the long-term memory. It records and stores all positive / negative experiences from intrauterine life to adulthood. Our subconscious contains emotions, behaviors, experiences and thinking style. The subconscious of women with fertility problems holds emotions such as inefficient, inadequate, unhappy. The women adopt a negative way of thinking during the diagnosis and treatment process and experience stress in terms of behavior [7]
(Figure 2). The critical factor is located between consciousness and subconscious. Our conscious does not accept messages without judgment. On the contrary, our subconscious accepts all messages, positive or negative.

The critical factor barrier comes into play with Hypnofertility and prevents negative messages from settling in the subconscious while allowing positive messages to settle. If there were negative messages in the subconscious before the application 
of Hypnofertility, the old messages are removed and new and therapeutic messages are placed. Because the subconscious stores a single message at the same time, new messages coming to the subconscious are stronger, and when it conflicts with the old one, it is always accepted a new one. Messages placed in the subconscious by crossing the critical factor barrier are transmitted to the autonomic system via neurotransmitters. The parasympathetic nervous system is stimulated, then it is ensured that GnRH, FSH, LH, estrogen and progesterone hormones are increased, fertilization and implantation are facilitated [7] (Figure 2).

\section{How Can We Affect the Consciousness in a Positive Way?}

The language of consciousness are words. Affirmations are used to positively affect consciousness. Affirmation is the positive expression of a discourse [15]. In order for affirmations to be effective, it must have 6P (Personal; Positive, Precise, Present Tense, Plausible, Practiced) feature. It should be personal, positive, precise, present, logical and practical. In the Hypnofertility method, instead of words such as infertile, unsuccessful, sterile, complete failure, complex, difficult, dysfunction, disorder, damage, deficiency, too late, it takes words such as fertile, fertility, productive, efficient, capable, sustainable, abundant, possible, developing, improving, hopeful. These are mentioned as the language of fertility in Hypnofertility [7].

The language of consciousness affirmations is transmitted via neurons to the Wernike field in the temporal lobe. Auditory information processed in the Wernike area is transmitted to the amygdala, where it is processed and transfered to the hippocampus, which acts as a channel. Incoming sensory signals are delivered to the hypothalamus to initiate chemical reactions appropriate to the signal. The hypothalamus, which acts as the center, sends messages to the left brain, where consciousness is located. The critical factor barrier is overcome by positively affecting consciousness. Chemical responses to messages are transmitted to the autonomic nervous system and hypothalamus. It transfers them to the anterior pituitary through efferent way. While transmitting to the anterior pituitary, GnRH released into the blood, LH and FSH release from the anterior pituitary, blood flow to the ovaries and estrogen and progesterone release from ovaries increase [7,9] (Figure 3). Let's explain with examples how affirmations can be applied to individuals with fertility problems:

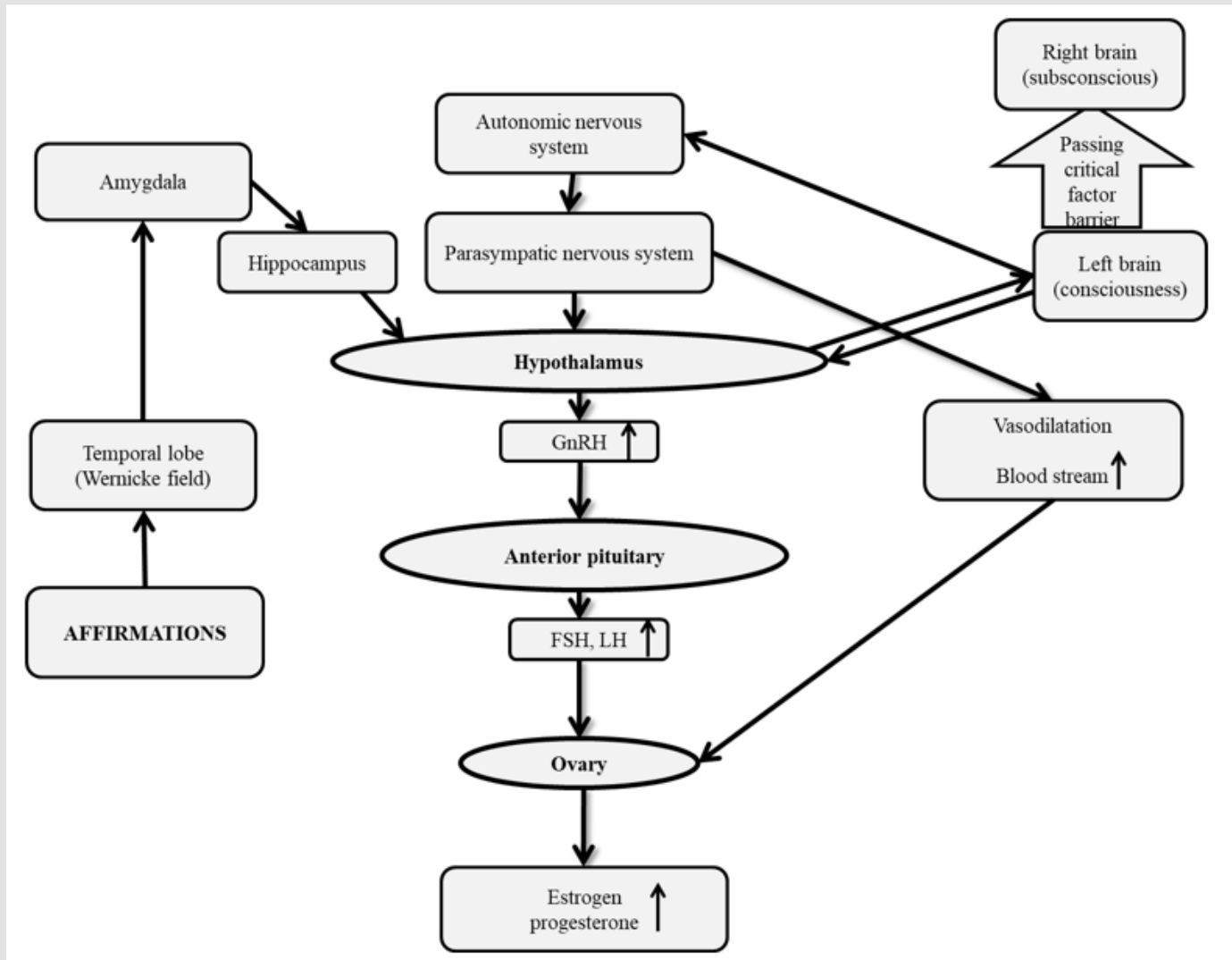

Figure 3: Neuroendocrine Effect of Affirmations on Fertility.

We can say to the woman whose follicles / oocytes are not sufficiently developed on the oocyte collection day, "Your eggs are still developing, we need more time to collect them" instead of saying "Your eggs are not developed, few and small". Instead of saying "You are not pregnant, treatment result is unsuccessful" to a woman who has a negative pregnancy test, we can say "You need more time and treatment to conceive, spend the time until the start of the treatment comfortably so that it affects the result positively." 
After consciousness is positively affected, personal boundaries are positively affected, turning into socialization, attitudes such as acceptance, belief that the treatment will be successful and conceiving, the decision to start or continue treatment, the hope of conceiving, and thoughts such as easy and feasible are occured.

How Can We Affect the Subconscious in a Positive Way?

The language of the subconscious is visualization, relaxation, and imagination. Frontal and parietal lobe using imagination, Wernike area located in the temporal lobe using relaxation, and occipital lobe using visualization are stimulated. Sensory information resulting from visualization, relaxation, and imagination is transmitted to the amygdala and from there to the hypothalamus via the hippocampus. The hypothalamus sends messages via afferent way to the right brain where the subconscious is located. If there are positive messages during visualization, relaxation and imagination, they are sent to the left brain and transmitted to the right brain after crossing the critical factor barrier.

Chemical responses to messages are transfered from the right brain to the autonomic nervous system and hypothalamus. The hypothalamus conveys it to the anterior pituitary via an efferent pathway. While passing to the anterior pituitary, GnRH released into the blood, LH and FSH release from the anterior pituitary, and estrogen and progesterone release from the ovaries increases $[7,9]$. At the same time, blood flow to the ovaries increases with the activation of the parasympathetic nervous system [13] (Figure 4). Let's clarify with examples how visualization, relaxation and imagination can be applied to individuals with fertility problems:

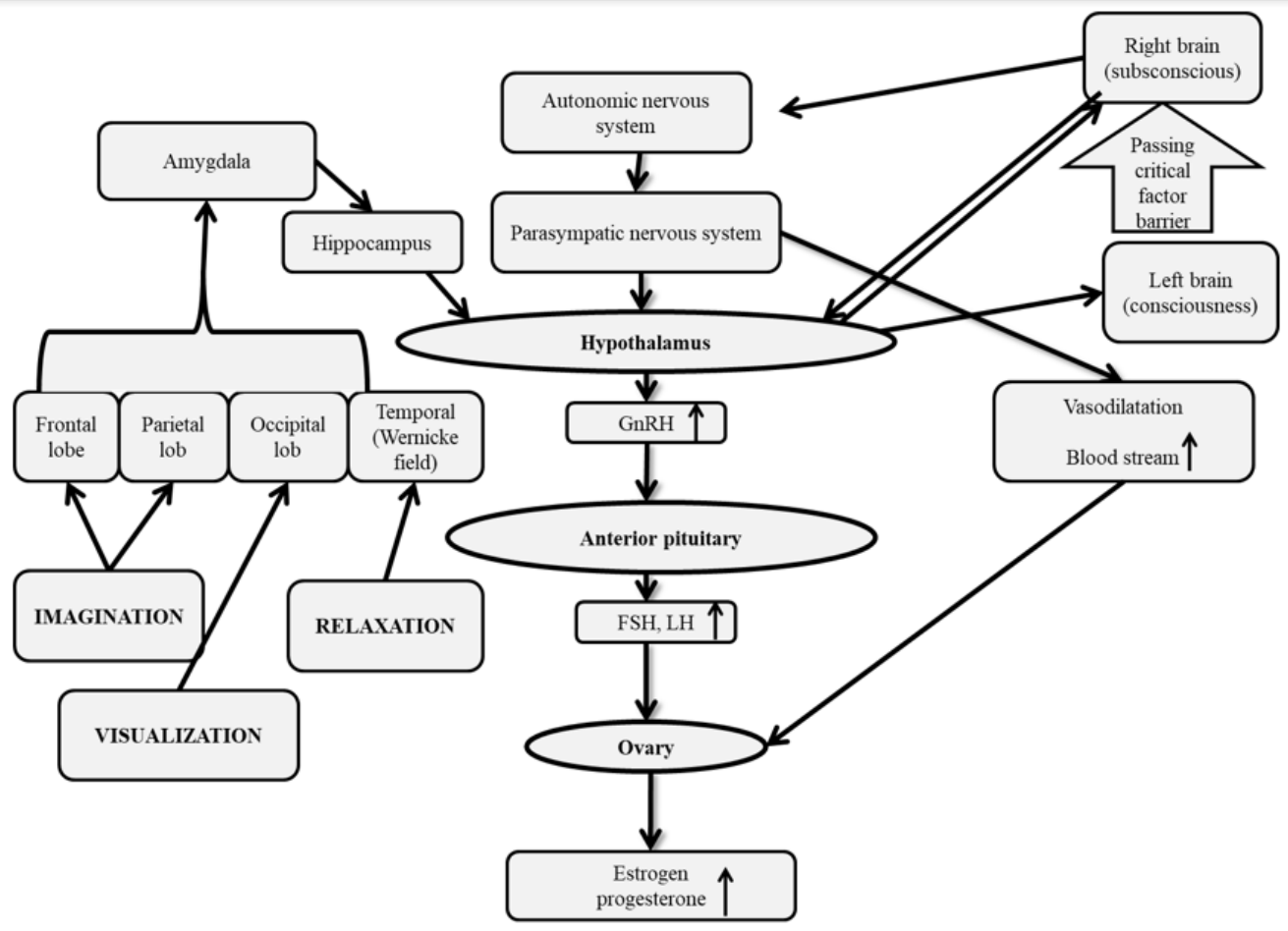

Figure 4: Neuroendocrine Effect of Visualization, Imagination, and Relaxation on Fertility.

\section{Visualization}

Creating a visual in the mind of a person and adding taste, smell and sound to it [16]. Visualization enables the parasympathetic nervous system to be activated and the HPG axis to be positively affected. For example, hanging pictures of couples who have children after treatment in the clinic can enable the woman to create the picture that she is in when she sees the pictures. As another example, when a woman visualizes her baby, she can create the baby picture in her mind, feel the smell, and hear the voice.

\section{Imagination}

It is the imagination of the place, the event and the time in which one can feel calm, relaxed and peaceful [17]. The aim of the technique is to mentally remove the individual from the uncomfortable environment, to reduce tension, to provide mental and physical relaxation [18]. For instance; imaging the blood flow to the uterus during and after the embryo transfer will activate the parasympathetic nervous system of the woman to relax and really increase the blood flow to the uterus.

\section{Relaxation}

It is the person's leaving his body to nothing. It is one of the techniques frequently used to get rid of the effects of stress. During relaxation, breathing exercises, imagination, visualization, mental 
space creation and music can be used [16]. With the breathing exercise, the air goes deep into the lungs and is breathing regularly $[16,17]$. By creating a mental space, the person feels comfortable and peaceful during relaxation [16]. The use of relaxing music with positive meaning or without words decreases cortisol hormone level and neuromuscular arousal and stimulates the parasympathetic nervous system [19-21]. For example, the fact that a relaxing, nonverbal music is played in the clinic, the use of breathing exercises and the mind area during the procedures will help the woman to relax.

As a result of visualization, relaxation and imagination, emotions turn into productive, sufficient and happy, the way of thinking about the diagnosis and treatment process turns into positive, and behavior turns into relaxation [7].

\section{How Can be Practiced Hypnofertility-Based Cursing Care?}

There are the experiences women have gained in the past and the messages they constantly receive. The nurse must first question these. A sample intervention plan based on the Hypnofertility-Based nursing care has been prepared, which can be applied by nurses from the first encounter with the woman receiving fertility support to the last interview (Table 1). In the intervention plan, according to the Hypnofertility method, how stress affects fertility, interventions that can be made for the areas affected in Hypnofertility to reduce stress are included. The intervention plan can be used in nursing care, individual or couple clinical practice. Thus, women will be evaluated in a holistic manner and psychosocial factors that negatively affect fertility will be determined and reduced.

Table 1: Hypnofertility-Based Nursing Care-Sample.

\begin{tabular}{|c|c|c|c|c|}
\hline Time & Purpose & Intervention & & $\begin{array}{l}\text { Areas affected in } \\
\text { hypnofertility }\end{array}$ \\
\hline \multirow{4}{*}{$\begin{array}{l}\text { In the first encounter } \\
\text { with the woman; }\end{array}$} & $\begin{array}{l}{ }^{*} \text { To reveal the negative } \\
\text { thoughts in the mind }\end{array}$ & $\begin{array}{l}\text { *Learning the positive or negative feelings, } \\
\text { thoughts, beliefs and behaviors in the } \\
\text { subconscious about infertility }\end{array}$ & Affirmation & $\begin{array}{l}\text { Thoughts Personal limits } \\
\text { (Consciousness) }\end{array}$ \\
\hline & $\begin{array}{l}\text { *To ensure that affirmations } \\
\text { affect the consciousness } \\
\text { positively }\end{array}$ & $\begin{array}{l}\text { *Using hypnofertility language } \\
\text { * Teaching to use affirmations at home } \\
\text { *Hanging affirmations in the waiting room }\end{array}$ & Affirmation & $\begin{array}{c}\text { Attitudes } \\
\text { Beliefs } \\
\text { Future Hope } \\
\text { Thoughts Decisions } \\
\text { (Consciousness) }\end{array}$ \\
\hline & $\begin{array}{l}\text { *Ensuring that the woman } \\
\text { affects her subconscious } \\
\text { positively through visualization }\end{array}$ & $\begin{array}{l}\text { *Using visualization by hanging pictures in } \\
\text { the waiting room } \\
\text { *Teach them to use visualization at home }\end{array}$ & Visualization & $\begin{array}{l}\text { Emotions } \\
\text { Thinking style } \\
\text { (Subconscious) }\end{array}$ \\
\hline & *Relaxing the woman & $\begin{array}{l}\text { *Using relaxation music in the clinic } \\
\text { *Teaching breathing exercises } \\
{ }^{*} \text { Teaching their use at home }\end{array}$ & Relaxing & $\begin{array}{l}\text { Emotions Behaviours } \\
\text { (Subconscious) }\end{array}$ \\
\hline \multirow{3}{*}{ In drug education; } & $\begin{array}{l}\text { *To ensure that affirmations } \\
\text { affect the consciousness } \\
\text { positively }\end{array}$ & $\begin{array}{c}\text { *Using hypnofertility language } \\
\text { *Writing affirmations to education rooms }\end{array}$ & Affirmation & $\begin{array}{c}\text { Attitudes } \\
\text { Beliefs } \\
\text { Future hope Thoughts } \\
\text { Decisions (Consciousness) }\end{array}$ \\
\hline & $\begin{array}{l}{ }^{*} \text { Ensuring that feelings of } \\
\text { anxiety and curiosity during } \\
\text { drug education are replaced by } \\
\text { feelings such as hope }\end{array}$ & $\begin{array}{l}\text { *Imaging that follicle / oocyte development } \\
\text { during drug education }\end{array}$ & Imagination & $\begin{array}{l}\text { Emotions Behaviours } \\
\text { Thinking style } \\
\text { (Subconscious) }\end{array}$ \\
\hline & *To make the woman relax & $\begin{array}{l}\text { *Using relaxation music } \\
\text { *Breathing Exercises }\end{array}$ & Relaxation & Behaviors (Subconscious) \\
\hline \multirow{2}{*}{$\begin{array}{l}\text { During examination } \\
\text { and procedure } \\
\text { days (Oocyte Pick- } \\
\text { up, Intrauterine } \\
\text { insemination, } \\
\text { Embryo transfer etc.); }\end{array}$} & $\begin{array}{l}\text { *To ensure that affirmations } \\
\text { affect the consciousness } \\
\text { positively }\end{array}$ & $\begin{array}{l}\text { *Using hypnofertility language } \\
\text { *Writing affirmations to examination rooms }\end{array}$ & Affirmative & $\begin{array}{l}\text { Future hope Thoughts } \\
\text { Decisions (Consciousness) }\end{array}$ \\
\hline & * To make the woman relax & $\begin{array}{l}\text { *Using relaxation music } \\
\text { *Breathing Exercises }\end{array}$ & Relaxation & Behaviors (Subconscious) \\
\hline $\begin{array}{l}\text { On the day of } \\
\text { pregnancy test; }\end{array}$ & $\begin{array}{l}\text { *To ensure that the } \\
\text { affirmations affect the } \\
\text { consciousness positively }\end{array}$ & *Using the language of Hypnofertility & Affirmation & $\begin{array}{c}\text { Attitudes } \\
\text { Beliefs } \\
\text { Future hope Thoughts } \\
\text { Decisions (Consciousness) }\end{array}$ \\
\hline
\end{tabular}




\section{Conclusion}

The fact that the Hypnofertility-Based nursing care is noninvasive, cheap and easily applicable is important for nurses to use in nursing care. Clinician nurses' use of this program in care will provide a systematic, holistic and knowledge-based approach to women. It is thought that the program will be effective in reducing the stress of the woman, increasing the pregnancy outcomes and changing the trust and perspective towards the nurse. Research nurses can also plan research on the subject in order to evaluate the effectiveness of Hypnofertility on the stress and pregnancy outcomes of women with fertility problems.

\section{References}

1. Hammarberg K, Astbury J, Baker HWG (2001) Women's Experience of IVF: A Follow-up Study. Human Reproduction 16(2): 374-383.

2. Klonoff-Cohen H, Chu E, Natarajan L, Sieber W (2001) A Prospective Study of Stress Among Women Undergoing In vitro Fertilization or Gamete İntrafallopian Transfer. Fertility and Sterility 76(4): 675-687.

3. Matthiesen SMS, Frederiksen Y, Ingerslev HJ, Zachariae R (2011) Stress, Distress and Outcome of Assisted Reproductive Technology (ART): A Meta- Analysis. Human Reproduction 26(10): 2763-2776.

4. Morreale M, Balon R, Tancer M, Diamond M (2010) The Impact of Stress and Psychosocial Interventions on Assisted Reproductive Technology Outcome. Journal of Sex \& Marital Therapy 37(1): 56-69.

5. Olivius K, Friden B, Borg G, Bergh C (2004) Why Do Couples Discontinue In Vitro Fertilization Treatment? A Cohort Study. Fertility and Sterility 81(2): 258-261.

6. Schmidt L, Holstein BE, Christensen U, Boivin J (2005) Communication and Coping as Predictors of Fertility Problem Stress: Cohort Study of 816 Participants Who Did Not Achieve A Delivery After 12 Months of Fertility Treatment. Human Reproduction 20(11): 3248-3256.

7. Gilbert S (2013) Fertility Support Program. Scottsdale, Arizona, USA.

ISSN: 2574-1241

DOI: 10.26717/BJSTR.2021.33.005428

Sevcan Fata. Biomed J Sci \& Tech Res

CC (P) This work is licensed under Creative

Submission Link: https://biomedres.us/submit-manuscript.php
8. Gordon JD, Speroff L (2003) Clinical Gynecologic Endocrinology and Infertility.

9. Guyton AC, Hall JE (2007) Medical Physiology.

10. Campagne DM (2006) Should fertilization treatment start with reducing stress? Human Reproduction 21(7): 1651-1658.

11. Strauss JF, Barbieri RL (2006) Yen and Jaffe's Reproductive Endocrinology. (Çeviri editörü: S, Günalp.) Yen\&Jaffe Üreme Endokrinolojisi. Güneş Kitabevi. Ankara.

12. Whirledge S, Cidlowski JA (2010) Glucocorticoids, Stress, and Fertility. Minerva Endocrinology 35(2): 109-125.

13. Forshee BA, Clayton MF, McCance KL (2010) Stress and Disease. In: McCance KL, Huether SE, Brashers VL, Rote NS Pathophysiology: The Biologic Basis for Disease in Adult and Children (pp. 336-351). $6^{\text {th }}$ Edition, Canada.

14. Mongan MF (2012) HypnoBirthing, Mongan Method. Istanbul: Gün Publishing.

15. Özkan B (2006) "Affirmation" and "Negation" as Grammatical Terms in Turkish (Türkçede Dilbilgisel Terim Olarak "Olumlama" ve "Olumsuzlama) Cukurova University Social Science Institute Journal 15(1): 269-282.

16. Köroğlu E (2011) Cognitive-Behavioral Therapies / Basic Concepts, Basic Approaches. HYB Publishing, $2^{\text {nd }}$ Edition. Ankara.

17. Braham JB (2002) Managing Stress: Keeping Calm Under Fire.

18. Okumuș H (2015) Natural Birth for Mother and Father Candidate. (Anne Baba adayları İçin Doğal Doğum). Istanbul: Deomed Publishing.

19. Fleury EAB, Approbato MS, Silva TM, Maia MCS (2014) Music Therapy in Stress: Proposal of Extension to Assisted Reproduction. Journal of Brezilian Assisted Reproduction 18(2): 55-61.

20. Kartın PT (2015) Müzik Terapi (Music Theraphy). Bașer M, Tașçı S (Ed.), Kanita Dayalı Rehberleriyle Tamamlayıcı ve Destekleyici Uygulamalar (Complementary and Supportive Practices with Evidence-Based Guides) (s. 9-14). Ankara: Akademisyen Tıp Kitabevi (Publisher).

21. Buckley SJ (2015) Hormonal Physiology of Childbearing: Evidence and Implications for Women, Babies, and Maternity Care.

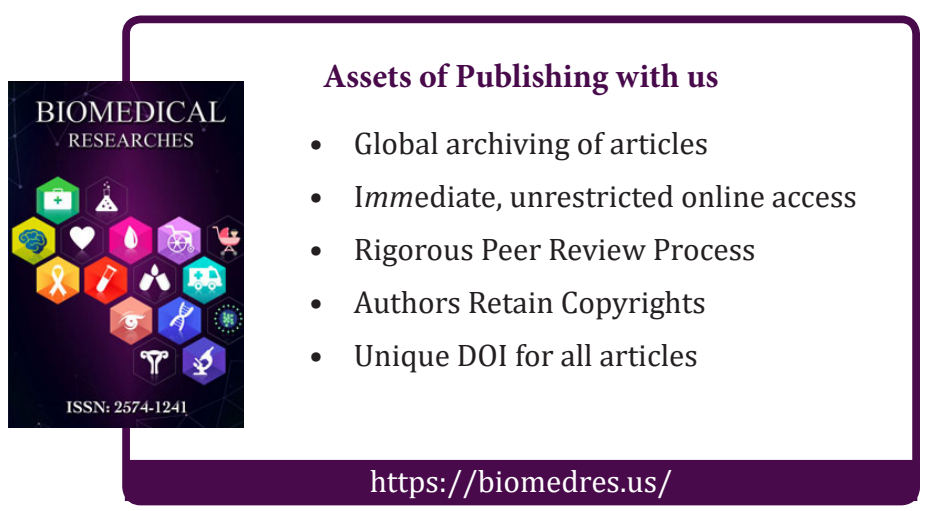

